\title{
DEVELOPMENT OF LIFE-PURPOSE ORIENTATIONS \\ OF MODERN UKRAINIAN YOUTH
}

https://doi.org/10.37096/SHDISJ-19-1.1-0005

E.O. Pomytkin,

https://orcid 0000-0002-2897-4769

O.V. Ivanova,

http://orcid.org/0000-0001-5962-9864

A.O. Parasiei-Hocher

https://orcid.org/0000-0002-1461-5060

\begin{abstract}
The paper covers basic results of the research of life-purpose orientations development of modern Ukrainian youth. The relevance of the research was determined by the insufficient life meaningful certainty of boys and girls. It was stated that the development of life-purpose orientations was progressive motion, directly related to the spiritual formation of personality. The theoretical analysis has shown that the discourse of scientific discussion on this issue is associated with attempts to integrate the views of various scientists, which are not contradictory but complementary. The psychodiagnostic research was conducted on the basis of the Secondary School of the I-III levels No. 1 of the city of Kyiv and Municipal Institution "M.I. Pirogov Humanitarian Gymnasium No. 1 of the Vinnytsia City Council", Kyiv Higher Vocational School of Sewing and Hairdressing, Kyiv Professional College with Enhanced Military and Physical Training, National Transport University and Khmelnitsky National University. 281 youths (from 15 to 22 years old) were involved in the research. The following diagnostic techniques were used at different stages of research: "Fulfillment of Desires" method by E.O. Pomytkin for identification of priority values and direction of value orientations of youth; "Research of the Life Meanings System" method of by V.Yu. Kotlyakov, for identification of actual life meanings and their correlation in the semantic structure of young personality; "Life-Purpose Orientations" test by D.O. Leontiev, for research of the life meaningfulness; "Spiritual Potential of Personality" method by E.O. Pomytkin, for diagnostics of spiritual potential and value orientations of young personality; "Diagnostics of the Reflexivity Development Level" method by A.V. Karpov, for research of the ability to reflection; "Scale of Assessment of the Achievement Motivation Level" by Yu.M. Orlov, for determination of the achievement motivation level of girls and boys; Demographic Questionnaire developed by the author, for determination of the influence of individual biological and socially determined factors on the development of life-purpose orientations in adolescence. On the basis of experimental data, the features of the phenomenon being researched are revealed, structure is systematized, psychological and pedagogical conditions for the development of life-purpose orientations in adolescence are determined, and model of their development is presented. The positive dynamics was revealed of the life-purpose orientations in adolescence as a result of approbation of the proposed psychological and pedagogical program of their development. Further prospects were determined of scientific search in the field of development of the life-purpose orientations of youth.
\end{abstract}

Keywords: life-purpose orientations, modern Ukrainian youth, adolescence, values, development, psychological and pedagogical program.

\section{Introduction}

At the beginning of the 21-st century the Ukrainian society faces global social challenges, including military incursion, economic and agricultural depression, destruction of the industrial complex, bureaucratization of education, massive migration of citizens, etc. The axiological strategic guidelines of self development declared by Ukraine do not usually have practical realization due to complex socio- political and economic realities. This determines the uncertainty of the life meanings and values of its citizens. It should be noted that just life meanings and values determine the leading motives of human activity and are reflected in human vitality. The aforementioned destructive tendencies have a lesser impact on the socially adapted adult population, but the problem of choosing the life-purpose orientations is extremely 
important for boys and girls who just choose the direction of self-development and self-realization.

The concept of "life-purpose orientations" in the psychological science is considered as a worldview component that reflects the vector of reality perception; as a directivity index of behavior and volitional actions of person in accordance with its spiritual axiological sphere and determination of own life purpose $[1,10,12$, $15,17,18,20]$. The specified concept is also associated with the key values of personality [14]; subjective-psychological time vectors of selfrealization of personality $[10,19]$; system of dominant values, motives and needs of personality within a specific semantic system [14]. The peculiarities of the worldview formation in adolescence are presented in scientific researches of the following scientists: O.I. Vlasova, L.G. Podolyak, T.M. Tytarenko, E.O. Pomytkin, V.V. Rybalka and others [2, 13, 14, 15, 17]. The lifepurpose orientations of person in youth days are generally interpreted by them as progressive forward motion directly related to the spiritual formation of personality, which is impossible without awareness of responsibility for own life and understanding of own role in relations with the external world.

Aim of the article is to show the effectiveness test results of the psychological and pedagogical program created for development of life-purpose orientations in adolescence.

Theoretical basis of the research. As a result of the analysis of philosophical and psychological content of the concept of life-purpose orientations of personality its central core - "life purpose" is singled out. According to V. Frankl, a person, his/her aspirations, ambitions and activity are always directed at something or someone in the external world [20]. This makes that sense, which realization is true for a person, which searching and finding is the primary incentive and "guide" in his/her life. In this sense, the "life purpose" may act as value or as choice of values guiding an individual in own life. Therefore, it is expedient the understanding of life-purpose orientations as a segment (substructure) of semantic psychic reality (which we consider in close relationship with the sphere of personal values), that performs specific regulatory and vital functions.

We consider the concept of the life-purpose orientations of personality in adolescence as an individual dynamic hierarchical structure of conscious and actual values-goals that constitute personal sense and determine the life spheres and vectors of person's activity in the period of adolescence.

The psychological and pedagogical conditions of development of the life-purpose orientations of personality in adolescence, based on the results of the theoretical analysis of the most progressive, in our opinion, psychological and pedagogical approaches to the development of life-purpose orientations of personality in this age (I.D. Bekh, S. D. Maksymenko, E.O. Pomytkin and other scientists) [1, 12, 15] are as follows: 1) organization of modern and staged value-semantic psychological and pedagogical influence on the personality formation in adolescence; 2) development of own life-purpose reflection; 3) development of achievement motivation; 4) special training of practical psychologists, social pedagogues, teachers and professors of educational institutions. Also, based on the personal-oriented approach to the personality development (I.D. Bekh, V.V. Rybalko, etc.) [1, 17], it was found that the development of lifepurpose orientations is impossible without spiritual tension of the subject, provided by a conscious volitional process. The volitional effort, moral and spiritual action are required as the first step to "appearance of a subject's state of spiritual tension" for the conscious volitional process to become characteristic of a young personality [1, p. 22].

Personal-oriented, activity-oriented, spiritualpersonal and transactional approaches compose the methodological basis of the empirical research. The psychodiagnostic tools were specified to carry out the experimental research of the life-purpose orientations of modern Ukrainian youth; and procedure was determined to carry out the research, which includes a forming experiment (assertion - formation - assertion).

Research findings. The total number of persons being researched was 281 respondents of the youth age from 15 to 22 years old: school students of 10-11 grades; students of technical schools of 1-2 courses of study; university students of 1 and 4 courses of study. The initial ascertaining experiment covered two stages. At the first stage, the pilot research was carried out using the method of the activity results evaluation, more specifically by writing a miniessay "My Key Goals, Values and Senses". The 
pilot experiment was provided on the basis of the secondary school of I-III stages No. 1 of the Shevchenko district of Kyiv and Interregional Higher Technical School of Communication in Kyiv. The research involved 148 participants (78 pupils and 70 students), 80 girls and 68 boys among them (45 girls and 33 boys among pupils, 35 girls and 35 boys among students accordingly). The analysis of the results obtained showed that $9 \%$ of boys and girls (10\% of pupils and $7 \%$ of students) could not answer the question asked; $34 \%$ ( $45 \%$ of pupils and $22 \%$ of students) noted only short-term goals. The most typical for boys and girls are: education (54\%); friends (44\%); family (34\%); altruism, social values (32\%); career (30\%); self-realization and selfdevelopment (25\%); status and honors (21\%); pleasure, hedonism (16\%); health (14\%); welfare (12\%). Also the following goals and values (14\%) were relevant: "to go as a volunteer in the ATO", "demonstration of patriotism and heroism", "peace in Ukraine", "education and living abroad".

To create a holistic picture of the development of life-purpose orientations of personality in adolescence, the following psychodiagnostic methods were included in the research program: 1 ) "Fulfillment of Desires" by E.O. Pomytkin, for identification of priority values and direction of value orientations of youth [16, p. 118]; 2) "Research of the Life Meanings System" by V.Yu. Kotlyakov, for identification of actual life meanings and their correlation in the semantic structure of young personality [9]; 3) "LifePurpose Orientations" test by D.O. Leontiev, for diagnostic purposes of features of the life purpose understanding [11]; 4) "Spiritual Potential of Personality" by E.O. Pomytkin, for determination of particularities of spiritual potential and value orientations development of young personality" [16, p.103]; 5) "Diagnostics of the Reflexivity Development Level" method by A.V. Karpov, for research of the ability to reflection of boys and girls [8]; 6) "Scale of Assessment of the Achievement Motivation Level" by Yu.M. Orlov, for determination of the achievement motivation level of girls and boys [7]; 7) Demographic Questionnaire developed by the author, for determination of the influence of natural and social factors on the development of life-purpose orientations in adolescence. The following statistical methods were used: Student's t-criterion (Student's T-test) for independent and dependent samples, ANOVA single-factor analysis of variance, d-Cohen effect strength criterion, Spearman's rank correlation coefficient and Ward's hierarchical cluster analysis (using the software version 17.0 of Statistical Package for the Social Science (SPSS) for Windows and Microsoft Excel 2016).

We processed the results of 281 young men; however, for 9 results (3.20\%), the allowable value (more than 4 points) was exceeded in terms of the level of transparency of the answers ("Spiritual Potential of Personality" method by E. Pomytkin). This may indicate a closed position, inattention or misunderstanding of questions. Since such data could introduce an unpredictable error into the research results, they were excluded from the analysis, and in general, 272 respondents (144 boys and 158 girls) were included in the sample, among them 72 pupils (29 boys and 43 girls), 75 students of technical schools (35 boys and 40 girls) and 125 university students (50 boys and 75 girls). The empirical data resulting from the ascertaining experiment conduction, showed an insufficiently high level of development of the life-purpose orientations among the representatives of adolescence. This determined to the need to create and provide within the framework of a formation experiment of the author's psychological and pedagogical program of the phenomenon being researched development as an element of the psychological and pedagogical support in the teaching process of educational institutions. It is based on the created psychological-pedagogical model of the life-purpose orientations development in adolescence (Figure 1) (see next page below).

Young boys and girls included in the groups with the lowest level of development of lifepurpose orientations were selected to participate in the experiment formation. 72 respondents participated totally in the experiment; 35 of them were included in the experimental group and passed the developed psychological-pedagogical program; 37 of them entered into the control group that did not participate in the program.

The basic empirical research of the lifepurpose orientations development of a personality in adolescence allowed to determine the level of life-purpose orientations development of youth (high, medium, low), which are differed by the content of values, meanings and structural links between them. 
It was found that young boys and girls with low level of the life-purpose orientations development have inherent family and hedonistic meanings; with middle level - cognitive, communicative, familiar and status meanings; with high level - altruistic meanings, selfrealization meaning, existential, cognitive and communicative meanings.

(Figure 1).

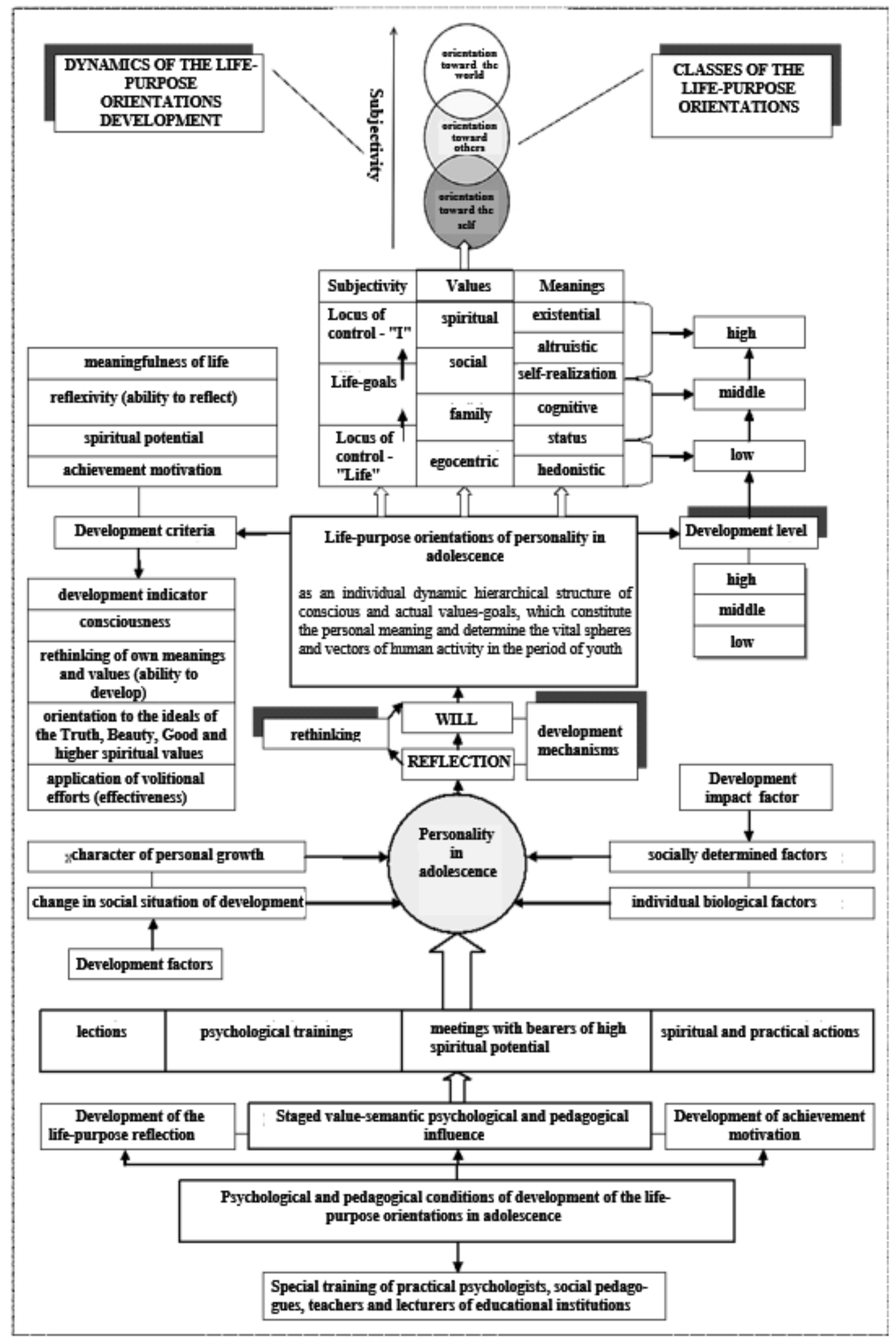

Fig. 1. Model of development of the life-purpose orientations in adolescence 
By means of their comparison, the features were revealed of the life-purpose orientations development of youth (complexity, differentiation and gradual qualitative transformation) from egocentric to spiritual values accompanied by appearance of new orientations, values and meanings. It was also determined in the research that the structure of spiritual potential of youth is formed by three hierarchical classes of the lifepurpose orientations: orientation toward the self and own needs, orientation toward other people and orientation toward the world and spiritual values. Their development is accompanied by increasing the subjectivity of young boys and complication of the value-semantic structure of their personality. The introduction of the psychological and pedagogical model of the lifepurpose orientations development in adolescence was the key point of approbation of the psychological and pedagogical program of development of the phenomenon being researched. The program approbation took place in 2016-2017 based on the Higher Technical School No. 25 of Khmelnitsky city (certificate No. 01-15/507 dated 08.11.2017), Kyiv Higher Technical School of Sewing and Hairdressing (certificate No. 139/1 dated 03.15.2018) and the Municipal Institution "M.I. Pirogov Humanitarian Gymnasium No. 1 of the Vinnytsia City Council" (certificate No. 236 dated 05.10.2018). Twelve meetings were held with total duration of 22 hours with each group of young boys and girls (high school students, college and technical school students, university students).

The experimental examination of the psychological and pedagogical program of the lifepurpose orientations development in adolescence confirmed its effectiveness. The obtained results confirmed the hypothesis that the life-purpose orientations development in adolescence was possible on the basis of organization of timely and staged psychological and pedagogical influence on the value-semantic formation of personality. The carried out research does not exhaust all possibilities for analysis of psychological features of the life-purpose orientations development of modern Ukrainian youth. Our further scientific searches are aimed at researching the influence of self-formation, particularities of character, temperament, mind, level of intellectual development and other individual characteristics of boys and girls on the formation and development of life-purpose orientations and determination of the sense of life at this age.

\section{Discussion}

The carried out theoretical and empirical analysis allowed determining that the problem of the life-purpose orientations development, particularly in adolescence, was researched in the works of both domestic and foreign scientists. They paid substantial attention to the problem of development of the phenomenon being researched in context of the age crisis and the selfdetermination problem during the period of youth. The meaning and correlation of the concepts of "life purpose" and "values" as key system-forming components of "the life-purpose orientations" concept were thoroughly analyzed. The high social significance was emphasized of researching the particularities of the life-purpose orientations development of young boys and girls in connection with the spiritual development of personality, in conditions of variable social reality. At the same time, the analysis carried out did not reveal fundamental researches of psychological particularities of the life-purpose orientations development in adolescence, which would have results that contradict the results of our research.

Conclusions. Therefore, in accordance with the purpose stated, the paper covers the theoretical basis of the problem of the life-purpose orientations development in adolescence; and ways of empirical research and development of the life-purpose orientations of modern Ukrainian youth were substantiated. In particular, the effectiveness of the author's psychological and pedagogical program of the life-purpose orientations development of modern Ukrainian youth was verified. As a result of its approbation, indicators of life meaningfulness, spiritual potential, ability to reflection, needs for achievements of youth were increased. Social values, meanings of self-realization, altruistic and cognitive meanings were actualized. Orientations appeared not only toward own needs, but also toward other people. Formation occurred of more active and conscious position for own life in general.

Despite the fact that the developed psychological and pedagogical program is effective and can be useful to teachers and psychologists in the process of the life-purpose orientations development of personality in adolescence and it can promote its successful 
socialization. The work implemented does not exhaust all possibilities of the analysis of phenomenon being investigated. The problem actualized in this work stimulates further deep research of the life-purpose orientations, in particular, as a volitional process. In addition, the influence of self-formation, character, temperament, mind features, level of intelligence and other individual characteristics of youth and adults on formation and development of the lifepurpose orientations remains insufficiently researched. This is the next step in our scientific research.

Conflict of interest. We state that there is no conflict of scientific interests.

\section{Referenses}

Bekh I. D. Dukhovna bezpechnist' - napruzhenist' u vykhovanni ta rozvytku osobystosti. Stanovlennya osobystosti : zb. nauk. prats'. Kam"yanets'-Podil's'kyy : Vydavets' PP Zvoleyko D.H., 2007. S. 18-24.

Vlasova O. I. Psykholohiya rozvytku sotsial'nyy zdibnostey osobystosti v ontohenezi (povnyy ontohenez) Naukova monohrafiya. - Ottava: AGC (Accent Graphics Communications). 2016. 377s.

Hrin'ova O. M. Ekzystentsiyni stratehiyi doslidzhennya smyslozhyttyevoho poshuku osobystosti. Materials of proceedings of the International Scientific and Practical conf. of pedagogues and psychologists «Scientific genesis”. The 8-th of August, 2014, Geneva, (Switzerland). 2014. № 2. S. 203-208.

Erikson E. Identichnost': yunost' i krizis / per. s angl. ; obshch. red. i predisl. A. V. Tolstykh. Moskva : Progress, 1996. 344 s..

Ivanova O. V. Psykholoho-pedahohichni pidkhody do rozvytku smyslozhyttyevykh oriyentatsiy osobystosti v yunats'komu vitsi. Aktual'ni problemy sotsiolohiyi, psykholohiyi, pedahohiky : zb. nauk. pr. Kyyiv : LOHOS, 2014. № 1 (22). S. 103-109.

Ivanova O. V. Rozvytok smyslozhyttyevykh oriyentatsiy yunakiv i divchat : metodychni rekomendatsiyi. Kyyiv : Vyd-vo NPU imeni M. P. Drahomanova, 2018. 36 s.

Exploring the need to achieve. Workshop on age psychology: studies. benefit / under. ed. : L. A. Golovei, E.F. Rybalko. SPb. : Peter, 2001. pp. 497-498.

Karpov A.V. Reflection test. Methods of diagnosing the level of reflexivity. [electronic resource]. URL: https://psycabi.net/testy/517test-refleksii-metodika-diagnostiki-urovnyarazvitiya-refleksivnosti-oprosnik-karpova-av.

Kotlyakov V. Yu. Methods of research of the system of life meanings. Siberian psychology today: Sat. scientific tr. Kemerovo: Kuzbassvuzuzdat, 2003. p. 18-21.

Leont'yev D. A. Empiricheskaya tipologiya smyslov zhizni v SSHA i Rossii. Smysl zhizni i akme : 10 let poiska : v 2-kh ch. / pod red. A. A. Bodaleva, G. A. Vayzer, N. A. Karpovoy, V. E. Chudnovskogo. Moskva, 2004. CH. 1. S. 72-81.

Leontiev D. A. Test of life sense orientations (LSS). Moscow: Meaning, 2000. 18 s.

Maksymenko S. D. Heneza zdiysnennya osobystosti : nauk. monohr. Kyyiv : TOV «KMM», 2006. 256 s.

Podolyak L. H., Yurchenko V. I. Psykholohiya vyshchoyi shkoly : navchal'nyy posibnyk. Kyyiv : TOV «Fil-studiya», 2006. 320 s.

Tytarenko T. M. Zhyttyevyy svit osobystosti u mezhakh i za mezhamy budennosti. Kyyiv : Lybid', 2003. 376 s.

Pomytkin E. O. Dukhovnyy potentsial osobystosti: psykholohichna diahnostyka, aktualizatsiya ta rozvytok : posibnyk. Kyyiv : Vnutrishniy svit, 2015. 144 s.

Pomitin E. O. Psychological diagnostics of the spiritual potential of the special features: friend. Kirovograd: Imeks-LTD, 2013. 144 s.

Rybalka V. V. Psykholohichni osoblyvosti odukhotvorennya osobystosti pedahohiv ta uchniv ta umov yikh navchal'no-vykhovnoyi diyal'nosti. Dukhovnist' osobystosti: metodolohiya, teoriya i praktyka : zbirnyk naukovykh prats' / hol. red. H. P. Shevchenko. Vyp. 6. (75). Syevyerodonets'k : vyd-vo SNU im. V. Dalya, 2017. S. 171-188.

Romenets' V. A., Manokha I. P. Istoriya psykholohiyi KHKH stolittya. Kyyiv : Lybid', 1998. S. 609.

Savchyn M. V. Dukhovna paradyhma psykholohiyi. Kyyiv : Akademiya, 2013. 252 $\mathrm{s}$.

Frankl V. E. Man in search of meaning: compilation / per. from english and him. D. A. Leontiev, M. P. Papusha, E. V. Eidman. Moscow: Progress, 1990. 372 s. 